\title{
Analysis of the Porosity and Microhardness of Glass Ionomer Cements
}

\author{
Inmaculada CABELLO MALAGÓN*, Basilio CÁNOVAS HERNÁNDEZ, \\ Elisa MARTÍNEZ HERNÁNDEZ, Clara SERNA-MUÑOZ, Amparo PÉREZ-SILVA, \\ Antonio José ORTIZ-RUIZ
}

\author{
Department of Integral Pediatric Dentistry, Faculty of Medicine, Hospital Morales Meseguer, University of Murcia, \\ 30007
}

cross ref $\mathrm{http}: / / \mathrm{dx}$.doi.org/10.5755/j02.ms.28198

Received 23 December 2020; accepted 20 April 2021

\begin{abstract}
Glass ionomer cements (GICs) are currently the first-choice materials in minimally invasive dentistry and are widely used in paediatric dentistry. The objective of this study was to evaluate the influence of viscosity and mixing on porosity and the relationship between the porosity and microhardness of GICs. Nine GICs were used: EQUIA ${ }^{\circledR}$ Forte Fil, Ionostar ${ }^{\circledR}$ Plus, $3 \mathrm{M}^{\mathrm{TM}}$ Ketac $^{\mathrm{TM}}$ Universal Aplicap $^{\mathrm{TM}}$, Riva Light Cure $\mathrm{HV}^{\circledR}{ }^{\circledR}$, Riva Silver ${ }^{\circledR}$, Riva Protect ${ }^{\circledR}$, Vitremer ${ }^{\mathrm{TM}}$, Vitrebond ${ }^{\mathrm{TM}}$ Plus and Activa BioActive Restorative ${ }^{\mathrm{TM}}$. Samples were prepared from each material and images were obtained by scanning electron microscopy (SEM). Using software, the number and diameter of pores, area, and percentage of area they occupied were measured. After SEM analysis, the samples were used to make surface microhardness (SMH) measurements. Ionostar ${ }^{\circledR}$ Plus, EQUIA ${ }^{\circledR}$ Forte Fil and Riva Light Cure $\mathrm{HV}^{\circledR}$ had the highest number of pores. Riva Protect ${ }^{\circledR}$ had the largest pores and the highest percentage of pore-occupied area, while Activa BioActive Restorative ${ }^{\mathrm{TM}}$ and Vitrebond ${ }^{\mathrm{TM}}$ Plus had a smaller pore size and a smaller percentage by area. Riva Silver ${ }^{\circledR}$ and EQUIA ${ }^{\circledR}$ Forte Fil showed the highest microhardness values and Vitrebond ${ }^{\mathrm{TM}}$ Plus and Vitremer $^{\mathrm{TM}}$ the lowest. In conclusion, when the cement viscosity is low, the type of mixture determines the degree of porosity, but has less influence when viscosity is high. There was no correlation between microhardness and the porosity of GICs.

Keywords: porosity, scanning electron microscopy, glass ionomer cement, viscosity, manual and mechanical mixing, microhardness.
\end{abstract}

\section{INTRODUCTION}

Glass ionomer cements (GICs) have good qualities such as biocompatibility, bioactivity, adhesion to dental structures, a coefficient of thermal expansion similar to the dental structure, and fluoride release, and is the dental material with the best biomimetic properties [1, 2].

However, GICs have worse mechanical properties than other restorative materials. To improve these properties, materials such as resin monomers, zinc, fibres, silica, nanocrystals, etc. have been incorporated into the powder and liquid phases of these cements [2-4]. Due to the improvements obtained through this process, the clinical use of GICs may be advised in both permanent and primary teeth and in restorations in the anterior and posterior sectors [2, 5]. In fact, GICs are currently the first-choice materials in minimally invasive dentistry for cavity management and are especially used in paediatric dentistry [6].

Resin-modified glass ionomer cements (RMGICs) have better mechanical properties and aesthetics than conventional GICs [7]. In addition, they have higher initial resistance and greater control of working time due to their twin setting reaction (chemical and light) [8].

GICs are commercially available in capsules for mechanical vibrating in an automix syringe and for manual mixing with a paper block spatula. All types of mixing incorporate air, resulting in the formation of pores in the cement, which worsens its mechanical properties, in particular, a decrease in the final resistance of the filling [9-11], due to the appearance of microcracks which, when propagated, cause marginal gaps in the restorations [12]. The appearance of pores in GICs may also facilitate greater adhesion of microorganisms on the surface of restorations due to increased roughness [8].

Glass ionomers have differing viscosities. Some studies have associated the failure of restorations using high viscosity glass ionomer cements (HVGICs), mainly used in atraumatic restoration treatments (ART), with a larger number of pores in these ionomers $[13,14]$.

Currently, there is no effective method of satisfactorily reducing the porosity of GICs. To avoid the formation of pores in GICs, a better understanding of their origins and adverse effects on the mechanical properties of GICs is required. This is done using observational techniques such as Scanning electron microscopy (SEM) and MicroComputed Tomography (Micro-CT), which permit the number, size, and distribution of pores in the material to be distinguished $[11,15]$. The physical-mechanical properties of GICs are characterized by the compressive strength, flexural strength and surface microhardness [16, 17]. Microhardness, defined as the resistance of a material to indentation or penetration [18], may be affected by the porosity.

The objectives of this study were to evaluate the influence of viscosity (high and low) and type of mixing (manual, mechanical and automix syringe) on the porosity

\footnotetext{
* Corresponding author. Tel.: +34 868888579.

E-mail address: icabello@um.es (I. Cabello Malagón)
} 
of GICs and study the relationship between the porosity and microhardness.

The null hypotheses were:(a) the viscosity and type of mixing did not influence the appearance of pores in GCIs; (b) the porosity does not influence the micro-hardening of GICs.

\section{EXPERIMENTAL DETAILS}

\subsection{Sample preparation}

We used the following GICs and prepared five samples for each study group, according to the manufacturers' instructions: five HVGICs with mechanical mixing:
EQUIA $^{\circledR}$ Forte Fil (GC Corp., Tokyo, Japan), Ionostar ${ }^{\circledR}$ Plus (Voco GmbH, Cuxhaven, Germany), $3 \mathrm{M}^{\mathrm{TM}} \mathrm{Ketac}^{\mathrm{TM}}$ Universal Aplicap ${ }^{\mathrm{TM}}$ (3M Deutschland GmbH, Neuss, Germany), Riva Light Cure $\mathrm{HV}^{\circledR}$ (SDI Limited. Bayswater, Victoria, Australia, Germany), Riva Silver ${ }^{\circledR}$ (SDI Limited. Bayswater, Victoria, Australia, Germany); one low viscosity (LVGIC) with mechanical mixing: Riva Protect ${ }^{\circledR}$ (SDI Limited. Bayswater, Victoria, Australia, Germany), one HVGIC with manual mixing: $\operatorname{Vitremer}^{\mathrm{TM}}$ (3M Deutschland GmbH, Neuss, Germany); one LVGIC with manual mixing: Vitrebond ${ }^{\mathrm{TM}}$ Plus (3M Deutschland GmbH, Neuss, Germany), and one LVGIC with an automix syringe (Activa BioActive Restorative $^{\mathrm{TM}}$ (Pulpdent $^{\circledR}$ ).

The composition of the materials is shown in Table 1.

Table 1. Composition and mode of application of glass ionomer cements used in the study

\begin{tabular}{|c|c|c|}
\hline Glass ionomer cement & Composition & Mode of application \\
\hline $\begin{array}{l}\text { EQUIA }^{\circledR} \text { Forte Fil } \\
\text { (GC Corp., Tokyo, Japan) }\end{array}$ & $\begin{array}{l}\text { Powder: } 95 \% \text { strontium fluoro-alumino-silicate } \\
\text { glass; } 5 \% \text { polyacrylic acid } \\
\text { Liquid: } 40 \% \text { aqueous polyacrylic acid }\end{array}$ & $\begin{array}{l}\text { - } \text { Apply cavity conditioner (10 sec) or dentin } \\
\text { conditioner ( } 20 \text { sec). } \\
\text { - } \text { Mix the capsule for } 10 \text { sec. } \\
\text { - } \quad \text { Load in GC capsule applier and apply. } \\
\text { - } \quad \text { A protective finished varnish (EQUIA Forte Coat) } \\
\text { should be applied. }\end{array}$ \\
\hline $\begin{array}{l}\text { Ionostar }{ }^{\circledR} \text { Plus } \\
\text { (Voco GmbH, Cuxhaven, Germany) }\end{array}$ & $\begin{array}{l}\text { Powder: fluoro-alumino-silicate glass, } \\
\text { polyacrylic acid, tartaric acid. } \\
\text { Liquid: polyacrylic acid solution }\end{array}$ & $\begin{array}{l}\text { - Activate the capsule. Mix the capsule for } 10 \text { sec, } \\
\text { insert it in an application device, and apply the } \\
\text { material directly into the cavity. } \\
\text { - }\end{array}$ \\
\hline 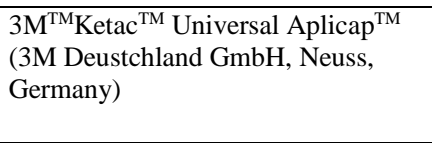 & $\begin{array}{l}\text { Powder: oxide glass chemicals } \\
\text { Liquid: water, copolymer of acrylic acid-maleic } \\
\text { acid, tartaric acid }\end{array}$ & 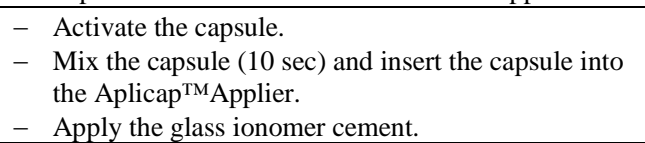 \\
\hline $\begin{array}{l}\text { Riva Light Cure HV } \\
\text { (SDI Limited. Bayswater, Victoria, } \\
\text { Australia, Germany) }\end{array}$ & $\begin{array}{l}\text { Liquid: acrylic acid homopolymer; } \\
\text { 2-hydroxyethyl methacrylate; dimethacrylate } \\
\text { cross-linker; acid monomer; tartaric acid. } \\
\text { Powder: glass powder. }\end{array}$ & $\begin{array}{l}\text { - Apply Riva Conditioner for } 10 \mathrm{sec} \text { and rinse with } \\
\text { water. } \\
\text { - Activate the capsule and immediately mix in an } \\
\text { amalgamator. } \\
\text { - Immediately place into the capsule applicator and } \\
\text { light cure, each increment } 20 \text { sec. }\end{array}$ \\
\hline $\begin{array}{l}\text { Riva Silver }^{\circledR} \\
\text { (SDI Limited. Bayswater, Victoria, } \\
\text { Australia, Germany) }\end{array}$ & $\begin{array}{l}\text { Liquid: acrylic acid homopolymer; tartaric acid. } \\
\text { Powder: glass powder; acrylic acid } \\
\text { homopolymer; alloy powder. }\end{array}$ & $\begin{array}{l}\text { - Apply Riva Conditioner for } 10 \text { seconds and rinse } \\
\text { with water. } \\
\text { - } \text { Remove excess water. Keep moist. } \\
\text { - Mix the capsule in an amalgamator OR mix the } \\
\text { powder/liquid combination on a mixing pad. Apply } \\
\text { Riva Protect to tooth surface. Apply Riva Coat and } \\
\text { light cure (20 sec). }\end{array}$ \\
\hline $\begin{array}{l}\text { Riva Protect }^{\circledR} \\
\text { (SDI Limited. Bayswater, Victoria, } \\
\text { Australia, Germany) }\end{array}$ & $\begin{array}{l}\text { Liquid: acrylic acid homopolymer; tartaric acid. } \\
\text { Powder: glass powder; acrylic acid } \\
\text { homopolymer, calcium amorphous phosphate } \\
{\left[\mathrm{Ca}_{3}\left(\mathrm{PO}_{4}\right)_{2}\right] \text {. }}\end{array}$ & $\begin{array}{l}\text { - Apply Riva Conditioner for } 10 \text { sec and rinse with } \\
\text { water. } \\
\text { - Mix the capsule in an amalgamator OR mix the } \\
\text { powder/liquid combination on a mixing pad. Apply } \\
\text { Riva Protect. } \\
\text { - When the material has lost its surface gloss, apply a } \\
\text { thin film of Riva Coat. } \\
\text { - } \quad \text { Light cure for } 20 \text { sec. }\end{array}$ \\
\hline $\begin{array}{l}\text { Vitremer }{ }^{\mathrm{TM}} \\
\text { (3M Deustchland GmbH, Neuss, } \\
\text { Germany) }\end{array}$ & $\begin{array}{l}\text { Powder: silane treated glass, potassium } \\
\text { persulfate. } \\
\text { Liquid: copolymer of acrylic and itaconic acids, } \\
\text { water, HEMA, ethyl acetate, diphenyl iodonium } \\
\text { hexafluorophosphate }\end{array}$ & $\begin{array}{l}\text { - Mix the powder into the liquid and place it into a 3M } \\
\text { ESPE dispenser. Place the material in a dry field. } \\
\text { - } \text { Light cure the glass ionomer for } 40 \text { sec. }\end{array}$ \\
\hline $\begin{array}{l}\text { Vitrebond }{ }^{\mathrm{TM}} \text { Plus } \\
\text { (3M Deustchland GmbH, Neuss, } \\
\text { Germany) }\end{array}$ & $\begin{array}{l}\text { Liquid: copolymer of acrylic and itaconic acids, } \\
\text { water, hydroxyethyl methacrylate (HEMA), } \\
\text { ethyl acetate, diphenyl iodonium } \\
\text { hexafluorophosphate, tetrahydrofuran. } \\
\text { Paste: silane treated glass, HEMA, water, } \\
\text { bisphenol A diglycidyl ether dimethacrylate } \\
\text { (Bis-GMA), silane-treated silica. }\end{array}$ & $\begin{array}{l}\text { - } \text { Apply dentin conditioner. } \\
\text { - } \text { Mix paste/liquid components }(10-15 \mathrm{sec}) \text { and apply. } \\
\text { - } \text { Light activation (20 sec). }\end{array}$ \\
\hline $\begin{array}{l}\text { ACTIVA BioACTIVE Restorative }{ }^{\mathrm{TM}} \\
\text { (Pulpdent }^{\circledR} \text { ) }\end{array}$ & $\begin{array}{l}\text { Paste/paste. Blend of diurethane and other } \\
\text { methacrylates with modified polyacrylic acid } \\
(44.6 \%) \text {, amorphous silica ( } 6.7 \%) \text {, and sodium } \\
\text { fluoride }(0.75 \%) \text {. }\end{array}$ & $\begin{array}{l}\text { - Etch } 10 \mathrm{sec} \text {, rinse and dry. } \\
\text { - Apply a bonding agent and place mix tip against the } \\
\text { floor of the cavity. } \\
\text { - Place a } 1-2 \mathrm{~mm} \text { insulating layer of ACTIVA and } \\
\text { light cure before bulk filling. }\end{array}$ \\
\hline
\end{tabular}


For groups with mechanical mixing, the capsules were mixed in a rotary vibrator $\left(3 \mathrm{M}^{\mathrm{TM}}\right.$ RotoMix ${ }^{\mathrm{TM}}$ Rotating Capsule Seefeld, Germany) and the material was introduced into standardized polypropylene tubes with an internal diameter of $4 \mathrm{~mm}$ and a height of $6 \mathrm{~mm}$ using an applicator gun. All samples, except for the self-curing cements, were photopolymerized for 20 sec using a SmartLite LED lamp (Dentsply®, USA) at $1250 \mathrm{~W} / \mathrm{cm}^{2}$. The samples were removed from the tube and cross-sectioned into $1 \mathrm{~mm}$ sections with a precision cutting machine (IsoMet 1000, BUEHLER, Illinois, USA), providing four sections per cylinder. Twelve sections were used for SEM and image analysis and five sections were used for micro hardening study. The samples used for SEM and image analysis were etched with $37 \%$ orthophosphoric acid for $5 \mathrm{sec}$, washed, and dried. They were then introduced in an ultrasonic machine (Calypso ${ }^{\circledR}$ - MESTRA) for $15 \mathrm{~min}$ immersed in $100 \%$ ethyl alcohol and left at room temperature for dehydration.

\subsection{SEM and image analysis}

Sample surfaces were coated with a thin layer of gold (BIO-RAD Polaron SEM Coating System) and placed in a vacuum chamber at a voltage of $2.5 \mathrm{kV}$ and an intensity of $20 \mathrm{~mA}$. The coating time of each plate was $4 \mathrm{~min}$. The samples were subsequently placed for analysis and observation using SEM (JSM-6100 JEOL), at a $400^{\mathrm{x}}$ magnification and a voltage of $15 \mathrm{kV}$, using INCA microanalysis suite software (Oxford Instruments, USA). Images were captured in 5 areas of each sample analysed. The area captured was $288 \times 288 \mu=82944 \mu^{2}$.

Image analysis was carried out using MIP 4ADVANCED software (Microm Image Processing Software, Digital Image Systems, Barcelona, Spain).

\subsection{Microhardness measurements}

Five samples in each group were used to study surface microhardness (SMH). SMH measurements were made using a Vickers diamond under a load of $100 \mathrm{~g}$ using a
Microhardness Tester FM-310 (FUTURE TECH CORP., Kawasaki, Japan).

The force was applied for $15 \mathrm{sec}$. Each specimen was indented three times and the mean Vickers hardness value was determined for each sample.

\subsection{Statistical analysis}

Independent variables were pore diameter, number of pores/areas, and microhardness, and the dependent variables were the total area and percentage of area per section. The sample size ( $n=12$ per group) was calculated using pore diameter values, and accepting an alpha risk of 0.05 , a beta risk of 0.20 (power 0.8 ) in a two-sided test to recognize a minimum difference of 4 units between any pair of groups, assuming that there were 9 groups. Common deviation was assumed to be 2.4. A drop-out rate of $0 \%$ was anticipated. Data are expressed as means \pm standard deviation (SD). The Shapiro-Wilk normality test was applied. As there was no normality, the Kruskal Wallis test was used to detect between-group differences and Dunn's test was used for two-by-two comparisons. To determine the interactions between the type of mixing and viscosity, we applied a robust ANOVA test. To establish possible correlations between variables, we used Pearson's correlation test. Statistical significance was established as $\mathrm{p}<0.05$.

\section{RESULTS}

\subsection{Number of pores per area}

Ionostar $^{\circledR}$ Plus (Figure 1A), EQUIA ${ }^{\circledR}$ Forte Fil (Fig. 1B) and Riva Light Cure HV® (Fig. 1 c) showed a significantly higher number of pores per section than other materials (Table 2).

\subsection{Pore size}

Riva Protect ${ }^{\circledR}$ had the largest pore-size $(32.213 \pm 8.519)$ (Fig. $1 \mathrm{~d}$ ). ACTIVA BioACTIVE Restorative ${ }^{\mathrm{TM}}$ $(3.990 \pm 3.034) \quad$ (Fig. 1 e) and Vitrebond ${ }^{\mathrm{TM}}$ Plus $(7.194 \pm 4.530)$ had the smallest pore sizes (Fig. $1 \mathrm{f}$ ) (Table 2).

Table 2. Number of pores/area $\left(82944 \mu \mathrm{m}^{2}\right)$, mean pore diameter $(\mu \mathrm{m})$, total area occupied by pores in each section $\left(82944 \mu \mathrm{m}^{2}\right)$ and percentage of area occupied by pores. Expressed as mean \pm standard deviation

\begin{tabular}{|c|c|c|c|c|c|c|c|}
\hline Material & $\begin{array}{c}\text { Number of } \\
\text { pores/area } \\
\left(82944 \mu \mathrm{m}^{2}\right)\end{array}$ & & Mean pore diameter & & $\begin{array}{c}\text { Total area occupied by } \\
\text { pores }\end{array}$ & $\begin{array}{c}\text { \% of area } \\
\text { occupied by pores }\end{array}$ & \\
\hline EQUIA $^{\circledR}$ Forte Fil & $11.081 \pm 5.955$ & $\mathrm{~b}$ & $15.890 \pm 4.085$ & b, c, d & $2749.746 \pm 1779.295$ & $3.315 \pm 2.145$ & b, c \\
\hline Ionostar ${ }^{\circledR}$ Plus & $15.300 \pm 7.498$ & & $10.379 \pm 4.252$ & & $1804.628 \pm 1386.520$ & $2.20 \pm 1.67$ & \\
\hline $\begin{array}{l}\text { 3M }{ }^{\mathrm{TM}} \text { Ketac }^{\mathrm{TM}} \text { Universal } \\
\text { Aplicap }\end{array}$ & $6.269 \pm 2.554$ & $\mathrm{a}$ & $21.102 \pm 7.457$ & a, b, c & $3183.019 \pm 2869.861$ & $3.838 \pm 3.460$ & b, c \\
\hline Riva Light Cure $\mathrm{HV}^{\circledR}$ & $7.967 \pm 2.988$ & $\mathrm{~b}$ & $21.627 \pm 9.450$ & $\mathrm{a}, \mathrm{b}, \mathrm{c}$ & $4221.295 \pm 3450.718$ & $5.089 \pm 4.160$ & $\mathrm{a}, \mathrm{b}, \mathrm{c}$ \\
\hline Riva Silver $^{\circledR}$ & $6.467 \pm 1.833$ & $\mathrm{a}$ & $22.313 \pm 9.150$ & $\mathrm{a}, \mathrm{b}, \mathrm{c}$ & $3506.631 \pm 2696.618$ & $4.228 \pm 3.251$ & b, c \\
\hline Riva Protect $^{\circledR}$ & $6.100 \pm 1.853$ & $\mathrm{a}$ & $32.213 \pm 8.519$ & $\mathrm{a}, \mathrm{b}, \mathrm{c}$ & $6147.767 \pm 2828.360$ & $7.412 \pm 3.410$ & $\mathrm{a}, \mathrm{b}, \mathrm{c}$ \\
\hline Vitremer $^{\mathrm{TM}}$ & $7.867 \pm 7.376$ & $\mathrm{a}$ & $14.828 \pm 6.895$ & b, c, d & $2357.998 \pm 1260.369$ & $2.843 \pm 1.520$ & $\mathrm{~b}, \mathrm{c}$ \\
\hline Vitrebond ${ }^{\mathrm{TM}}$ Plus & $6.000 \pm 6.641$ & $\mathrm{a}$ & $7.194 \pm 4.530$ & & $441.055 \pm 682.527$ & $0.532 \pm 0.823$ & $\mathrm{a}$ \\
\hline $\begin{array}{l}\text { ACTIVA BioACTIVE } \\
\text { Restorative }^{\text {TM }}\end{array}$ & $7.400 \pm 4.262$ & $\mathrm{a}$ & $3.990 \pm 3.034$ & $\mathrm{a}$ & $395.719 \pm 1309.223$ & $0.477 \pm 1.578$ & $\mathrm{a}$ \\
\hline
\end{tabular}




\subsection{Total area and percentage of area per section}

ACTIVA

BioACTIVE

Restorative $^{\mathrm{TM}}$ $(395.719 \pm 1309.223) \quad$ (Fig. 1 e) and Vitrebond ${ }^{\mathrm{TM}}$ Plus $(441.055 \pm 682.527)$ (Fig. $1 \mathrm{f})$ had the smallest area occupied by pores. Riva Protect ${ }^{\circledR}(6147.767 \pm 2828.360)$ (Fig. $1 \mathrm{~d}$ ) followed by Riva Light Cure $\mathrm{HV}^{\circledR}$ $(4221.295 \pm 3450.718)$ (Fig. $1 \mathrm{c})$ had the largest area occupied by pores (Table 2 ).

\subsection{Interaction between the type of mixing and the degree of viscosity}

We found no association in the number of pores per area between the type of mixing and the degree of viscosity ( $p=0.769$ ), but there was an association between the mean pore diameter $(p=0.001)$ and the total area occupied by pores $(p=0.002)$, showing that high viscosity ionomers were little influenced by these two factors, while in low viscosity ionomers (fluids), mechanical mixing produced larger pores and a larger occupied area than manual mixing.

\subsection{Microhardness}

Riva Silver $^{\circledR}(116.633 \pm 14.659)$ and EQUIA ${ }^{\circledR}$ Forte Fil $(81.105 \pm 7.716)$ showed the highest microhardness values.
Vitrebond $^{\mathrm{TM}}$ Plus $(27.335 \pm 6.019)$ followed by Vitremer ${ }^{\mathrm{TM}}$ (23.375 \pm 4.648$)$ showed the lowest (Table 3).

There was no correlation between microhardness and the number of pores per area, pore diameter, total area, and percentage of area per section (Pearson's correlation test) (Table 4).

Table 3. Surface microhardness (Vickers hardness-VHN) values for each group. Expressed as mean \pm standard deviation

\begin{tabular}{|c|c|c|}
\hline Material & Microhardness & $\begin{array}{c}\text { Statistical } \\
\text { significance }\end{array}$ \\
\hline EQUIA $^{\circledR}$ Forte Fil & $81.105 \pm 7.716$ & \\
\hline Ionostar ${ }^{\circledR}$ Plus & $45.237 \pm 10.70$ & $a, b, c$ \\
\hline $\begin{array}{l}\text { 3M }^{\mathrm{TM}} \text { Ketac }^{\mathrm{TM}} \\
\text { Universal Aplicap }^{\mathrm{TM}}\end{array}$ & $76.494 \pm 6.364$ & \\
\hline Riva Light Cure $\mathrm{HV}^{\circledR}$ & $54.182 \pm 8.865$ & $\mathrm{a}$ \\
\hline Riva Silver ${ }^{\circledR}$ & $116.633 \pm 14.659$ & \\
\hline Riva Protect $^{\circledR}$ & $54.777 \pm 6.469$ & $\mathrm{a}$ \\
\hline Vitremer $^{\mathrm{TM}}$ & $23.375 \pm 4.648$ & a, b, c, d, e \\
\hline Vitrebond ${ }^{\mathrm{TM}}$ Plus & $27.335 \pm 6.019$ & a, b, c, d, e \\
\hline $\begin{array}{l}\text { ACTIVA BioACTIVE } \\
\text { Restorative }^{\mathrm{TM}}\end{array}$ & $36.975 \pm 7.3$ & $a, b, c$ \\
\hline \multicolumn{3}{|c|}{$\begin{array}{l}\text { Statistical significance: a, vs. Riva Silver }{ }^{\circledR} \text {; b, vs. EQUIA }{ }^{\circledR} \\
\text { Forte Fil; c, 3MTMKetacTM Universal AplicapTM,; d, Riva } \\
\text { Protect }{ }^{\circledR} \text {; e, Riva Light Cure HV® }\end{array}$} \\
\hline
\end{tabular}
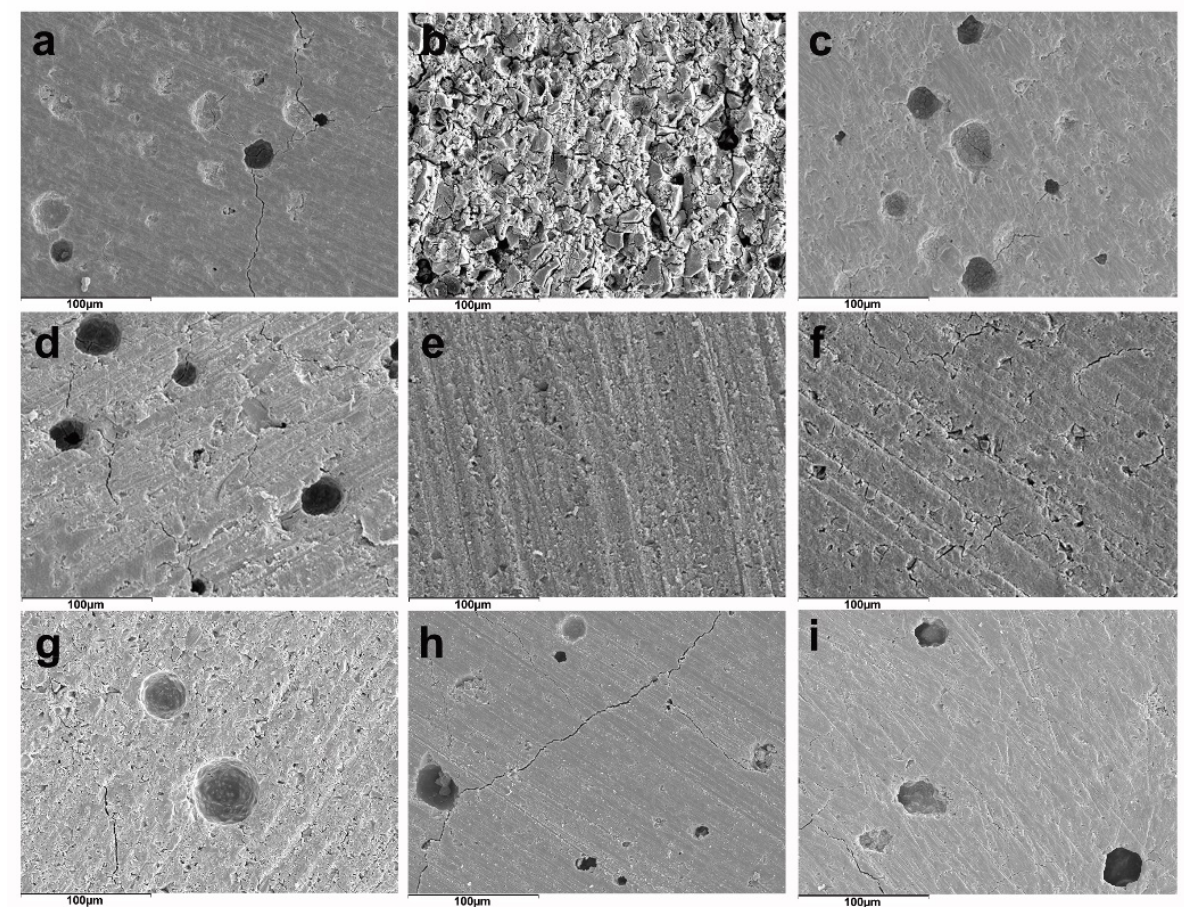

Fig. 1. Scanning Electron Microscopy at $400^{\mathrm{x}}$ magnification of: a-Ionostar ${ }^{\circledR}$ Plus; b-EQUIA ${ }^{\circledR}$ Forte Fil; c-Riva Light Cure HV ${ }^{\circledR}$; $\mathrm{d}$-Riva $\quad$ Protect $^{\circledR} ; \quad \mathrm{e}$-ACTIVA $\quad$ BioACTIVE $\quad$ Restorative $^{\mathrm{TM}} ; \quad \mathrm{f}$-Vitrebond ${ }^{\mathrm{TM}} \quad$ Plus; $\mathrm{g}^{\mathrm{B}}$-Vitremer ${ }^{\mathrm{TM}}$; $\mathrm{h}-3 \mathrm{M}^{\mathrm{TM}}$ Ketac $^{\mathrm{TM}}$ UniversalAplicap $^{\mathrm{TM}} ; \mathrm{i}-$ Riva Silver $^{\circledR}$

Table 4. Pearson's correlation test results of surface microhardness and number of pores per area, pore diameter, total area and percentage of area per section

\begin{tabular}{|c|c|c|c|c|}
\hline & Microhardness & $\begin{array}{c}\% \text { of area occupied by } \\
\text { pores }\end{array}$ & $\begin{array}{c}\text { Total area occupied } \\
\text { by pores }\end{array}$ & $\begin{array}{c}\text { Number of pores per } \\
\text { area }\end{array}$ \\
\hline Pore diameter & cc: $0.492 ; p=0.179$ & cc: $0.981 ; p<0.001$ & cc: $0.981 ; p<0.001$ & cc: $0.314 ; p=0.410$ \\
\hline Microhardness & & cc: $0.429 ; p=0.179$ & cc: $0.429 ; p=0.179$ & cc: $-0.0785 ; p=0.841$ \\
\hline$\%$ of area occupied by pores & & & cc: $1.000 ; p<0.001$ & cc: $-0.209 ; p=0.589$ \\
\hline Total area occupied by pores & & & & cc: $-0.207 ; p=0.593$ \\
\hline
\end{tabular}




\section{DISCUSSION}

The results of this study show that two HVGICs, Ionostar $^{\circledR}$ Plus and EQUIA ${ }^{\circledR}$ Forte Fil, had the highest number of pores per section, and a LVGIC (Vitrebond ${ }^{\mathrm{TM}}$ Plus), had the fewest pores per section. This direct relationship between the high viscosity of glass ionomer cement and the presence of a large proportion of pores has also been described by other authors as a result of increased incorporation of air bubbles during the mixing process in HVGICs [10, 11, 19, 20-22]. Other authors, however, found more pores in LVGICs [21, 22].

Considering all materials, manual mixing generated pores with a mean diameter of $8.702 \pm 1.146 \mu \mathrm{m}$, mechanical mixing $20.006 \pm 0.999 \mu \mathrm{m}$ and the automix syringe $2.783 \pm 1.83 \mu \mathrm{m}$. For the diameter of the pores, the type of mixing showed a significant interaction with the viscosity level of the ionomers, so that in HVGICs the type of mixing did not significantly influence the pore diameter, while it was decisive for LVGICs. Thus, manual mixing in fluid ionomers generated smaller diameter pores than mechanical mixing.

Vitrebond $^{\mathrm{TM}}$ Plus, with low viscosity and manual mixing, showed pores with a diameter of $7.194 \pm 4.530 \mu \mathrm{m}$, while Riva Protect ${ }^{\circledR}$ with low viscosity and mechanical mixing, had the largest diameter pores (32.213 $\pm 8.5197 \mu \mathrm{m})$. Al-Kadhim et al. [23] also found that glass isomer cement in capsules (Fuji I CAPSULE) had pores with a greater diameter than manually mixed cement (Fuji I).

The same interaction between the type of mixing and the degree of viscosity observed for the size of the pores was also found for the area the pores occupied. Thus, the type of mixing was decisive for LVGICs. Manual mixing in Vitrebond $^{\mathrm{TM}}$ Plus generated the lowest proportion of pores and mechanical mixing in Riva Protect $^{\circledR}$ the highest proportion. With the great speed of mechanical mixing, the low viscosity of the material would allow the formation of more and smaller air bubbles, similar to a "froth". The slower process of manual mixing would prevent the inclusion of air and cause some bubbles to collapse [23-26]. However, some reports have described conflicting results, suggesting that manual mixing can incorporate air during the process and that automatic mixing would help prevent this by producing smaller pores and fewer large pores [15, 27].

The ionomer with the smallest diameter pores and the smallest area/proportion of pores was ACTIVA BioACTIVE Restorative ${ }^{\mathrm{TM}}$, available in an automix syringe, probably because it is not subjected to spatulation or mechanical mixing, thus reducing the incorporation of air bubbles.

Further study of the advantages that the automix syringe system could provide in the porosity of GICs is required.

Riva Silver $^{\circledR}(116.633 \pm 14.659)$ and EQUIA ${ }^{\circledR}$ Forte Fil (81.105 \pm 7.716$)$ had the highest micro-hardening values. Riva Silver ${ }^{\circledR}$ showed the highest microhardness. These results are similar to those obtained by Nanda and Naik [28] and Yin et al. [29], who compared a conventional GIC with others whose composition included silver particles which, in addition to improving the mechanical properties of these materials, has an antibacterial effect, and is often used in restorative dentistry.

Hershkovitz et al. [30] obtained better microhardness results at $60 \mathrm{~min}$. with EQUIA Fil versus Riva Self Cure and Ketac Molar. Sidhu [31] suggested the better mechanical properties of this high viscosity cement was due to greater crosslinking of the finest glass particles.

Two GICs using manual mixing had the lowest microhardness; Vitrebond ${ }^{\mathrm{TM}}$ Plus (27.335 \pm 6.019$)$ and Vitremer $^{\mathrm{TM}}$ (23.375 \pm 4.648). Al-Taee et al. [17] also found that microhardness, the modulus of elasticity, and compression force, among other factors, were higher in GICs and RMGICs with mechanical mixing compared with those with manual mixing. They also found less porosity of the material if it used mechanical mixing, with an improvement in mechanical properties. However, we could not correlate the microhardness with the porosity of the GICs studied. Nor could we find any correlation between the viscosity and microhardness of the GICs, as has been shown in other studies [13,17,32].

Although the microhardness and the modulus of elasticity of the dentin are similar to those of GICs [33], these properties may be influenced by the operator's handling and insertion techniques of the GICs, and therefore the lower microhardness values in GICs with manual mixing may be due to unintentional alterations in the powder/liquid proportions when mixing the cement [13]. Therefore, in order not to alter this proportion and its mechanical properties, many authors suggest using only GICs with mechanical mixing [34].

According to the results of our study, we can partially reject the first null hypothesis since, regarding porosity, the type of mixing was only decisive in low viscosity ionomers and accept the second null hypothesis, since porosity did not influence the microhardness of the GICs studied.

\section{CONCLUSIONS}

The main strength of this study is the large number of GICs studied and the detailed analysis.

The results show that when the viscosity of glass ionomer cement is low, the size of the pores and the area they occupy depend on the type of mixing while, when the viscosity is high, the type of mixture has less influence. The automix syringe system seems to provide better porosity results. There was no relationship between porosity and microhardness.

Among all materials studied, EQUIA ${ }^{\circledR}$ Forte Fil and $3 \mathrm{M}^{\mathrm{TM}} \mathrm{Ketac}^{\mathrm{TM}}{ }$ UniversalAplicap ${ }^{\mathrm{TM}}$ may be recommended for clinical use as they had a high level of microhardness and intermediate porosity.

\section{REFERENCES}

1. Sidhu, S.K., Nicholson, J.W. A Review of Glass-Ionomer Cements for Clinical Dentistry Journal of Functional Biomaterials 7 (3) 2016: pp. 16. https://doi.org/10.3390/jfb7030016

2. Menezes-Silva, $R$., Fernandes, P.H.M., Shimohara, L.Y., $\quad$ Pereira, F.V., Borges, A.F.S., $\quad$ Buzalaf, M.A.R., $\quad$ Pascotto, R.C., Sidhu, S.K., de Lima Navarro, M.F. Effects of the 
Reinforced Cellulose Nanocrystals on Glass-Ionomer Cements Dental Materials 35 (4) 2019: pp. 564-573. https://doi.org/10.1016/j.dental.2019.01.006

3. Tjandrawinata, R., Irie, M., Yoshida, Y., Suzuki, K. Effect of Adding Spherical Silica Filler on PhysicoMechanical Properties of Resin Modified Glass Ionomer Cement Dental Materials Journal 23 (2) 2004: pp. $146-154$. https://doi.org/10.4012/dmj.23.146

4. Silva, R.M., Pereira, F.V., Mota, F.A.P., Watanabe, E., Soares, S.M., Santos, M.H. Dental Glass Ionomer Cement Reinforced by Cellulose Microfibers and Cellulose Nanocrystals Materials Science \& Engineering C, Materials for Biological Applications 58 2016: pp. 389-395. https://doi.org/10.1016/j.msec.2015.08.041

5. Gurgan, S., $\quad$ Kutuk, Z.B., $\quad$ Ergin, E., $\quad$ Oztas, S.S., Cakir, F.Y. Four-year Randomized Clinical Trial to Evaluate the Clinical Performance of a Glass Ionomer Restorative System Operative Dentistry 40 (2) 2015: pp. 134-143. https://doi.org/10.2341/13-239-C

6. Berg, J.H., Croll, T.P. Glass Ionomer Restorative Cement Systems: An Update Pediatric Dentistry $37(2)$ 2015: pp. 116-124.

7. Qvist, V., Poulsen, A., Teglers, P.T., Mjor, I.A. The Longevity of Different Restorations in Primary Teeth International Journal of Paediatric Dentistry $20(1)$ 2010: pp. $1-7$.

https://doi.org/10.1111/j.1365-263X.2009.01017.x

8. Moberg, M., Brewster, J., Nicholson, J., Roberts, $\mathbf{H}$. Physical Property Investigation of Contemporary Glass Ionomer and Resin-Modified Glass Ionomer Restorative Materials Clinical Oral Investigations 23 (3) 2019: pp. $1295-1308$.

https://doi.org/10.1007/s00784-018-2554-3

9. McLean, J.W. Clinical Applications of Glass-Ionomer Cements Operative Dentistry Suppl 5 1992: pp. 184-190.

10. Covey, D.A., Ewoldsen, N.O. Porosity in Manually and Machine Mixed Resin-Modified Glass Ionomer Cements Operative Dentistry 26 2001: pp. 617-623.

11. Nomoto, R., McCabe, J.F. Effect of Mixing Methods on the Compressive Strength of Glass Ionomer Cements Journal of Dentistry 29 (3) 2001: pp. 205-210. https://doi.org/10.1016/s0300-5712(01)00010-0

12. Menezes-Silva, R., Cabral, R.N., $\quad$ Pascotto, R.C., Borges, A.F.S., Martins, C.C., $\quad$ Navarro, M.F.L., Sidhu, S.K., Leal, S.C. Mechanical and Optical Properties of Conventional Restorative Glass-Ionomer Cements-A Systematic Review Journal of Applied Oral Science 27 2019: pp. e2018357. https://doi.org/10.1590/1678-7757-2018-0357

13. Hironaka, N.G.L., $\quad$ Trizzi, J.Q., $\quad$ Yoshida, N.M., Cury, J.A., Tabchoury, C.P.M., Botelho, J.N., Pini, N.I.P., Pascotto, R.C. Use of Sonic Waves in Bubble Formation, Microhardness and Fluoride Release of a High-Viscosity Glass-Ionomer Cement Journal of Investigative and Clinical Dentistry 10 (4) 2019: pp. e12456. https://doi.org/10.1111/jicd.12456

14. Faustino-Silva, D.D., Figueiredo, M.C. Atraumatic Restorative Treatment-ART in Early Childhood Caries in Babies: 4 Years of Randomized Clinical Trial Clinical Oral Investigations 23 (10) 2019: pp. 3721-3729. https://doi.org/10.1007/s00784-019-02800-8

15. Malkoç, M.A., Sevimay, M., Tatar, İ., Çelik, H.H. MicroCT Detection and Characterization of Porosity in Luting
Cements Journal of Prosthodontics

2015: pp. 553-561.

https://doi.org/10.1111/jopr.12251

16. Pameijer, C.H., Garcia-Godoy, F., Morrow, B.R., Jefferies, S.R. Flexural Strength and Flexural Fatigue Properties of Resin-Modified Glass Ionomers The Journal of Clinical Dentistry 26 (1) 2015: pp. 23 - 27.

17. Al-Taee, L., Deb, S., Banerjee, A. An in vitro Assessment of the Physical Properties of Manually- Mixed and Encapsulated Glass-Ionomer Cements British Dental Journal Open 6 2020: pp. 12.

https://doi.org/10.1038/s41405-020-0040-x

18. Silva, R.C., $\quad$ Zuanon, A.C., $\quad$ Esberard, R.R., Candido, M.S., Machado, J.S. In Vitro Microhardness of Glass Ionomer Cements Journal of Materials Science: Materials in Medicine 18 (1) 2007: 139-142. https://doi.org/10.1007/s10856-006-0672-y

19. Geirsson, J., Thompson, J.Y., Bayne, S.C. Porosity Evaluation and Pore Size Distribution of a Novel Directly Placed Ceramic Restorative Material Dental Materials 20 (10) 2004: pp. 987-995. https://doi.org/10.1016/j.dental.2004.07.003

20. Bertenshaw, B.W., Piddock, V. Porosity in Water-Based Dental Luting Cements Journal of Materials Science: Materials in Medicine 4 1993: pp. 415-417. https://doi.org/10.1007/BF00122201

21. Mitchell, C.A., Douglas, W.H. Comparison of the Porosity of Hand-Mixed and Capsulated Glass-Ionomer Luting Cements Biomaterials 18 (16) 1997: pp. 1127-1131. https://doi.org/10.1016/s0142-9612(97)00038-0

22. Issa, M., Brunton, P., Silikas, N., Watts, D.C. Expulsion Force, Surface $\mathrm{pH}$, and Porosity of Encapsulated GlassIonomer Cements Mixed with a Rotomix Device The European Journal of Prosthodontics and Restorative Dentistry 10 (3) 2002: pp. 119-123.

23. Al-Kadhim, A., Abdullah, H., Mahmood, A. Effect of Porosity on Compressive Strength of Glass Ionomer Cements Malaysian Dental Journal 34 (1) 2012: pp. 23-29.

24. Nomoto, R., Komoriyama, M., McCabe, J.F., Hirano, S. Effect of Mixing Method on the Porosity of Encapsulated Glass Ionomer Cement Dental Materials $20(10)$ 2004: pp. $972-978$. https://doi.org/10.1016/j.dental.2004.03.001

25. Arcoria, C.J., Butler, J.R., Wagner, M.J., Vitasek, B.A. Bending Strength of Fuji and Ketac Glass Ionomers after Sonication Journal of Oral Rehabilitation 19 (6) 1992: pp. 607-613.

https://doi.org/10.1111/j.1365-2842.1992.tb01490.x

26. Coldebella, C.R., Santos-Pinto, L., Zuanon, A.C.C. Effect of Ultrasonic Excitation on the Porosity of Glass Ionomer Cement: a Scanning Electron Microscope Evaluation Microscopy Research and Technique 74 (1) 2011: pp. 54-57. https://doi.org/10.1002/jemt.20873

27. Fleming, G.J.P., Kenny, S.M., Barralet, J.E. The Optimisation of the Initial Viscosity of an Encapsulated Glass-Ionomer Restorative following Different Mechanical Mixing Regimes Journal of Dentistry 34 (2) 2006: pp. $155-163$. https://doi.org/10.1016/j.jdent.2005.05.008

28. Nanda, K.J., Naik, S. An In-Vitro Comparative Evaluation of Pre-treatment with Nano-Silver Fluoride on Inhibiting Secondary Caries at Tooth Restoration Interface Cureus 12 (5) 2020: pp. e7934. https://doi.org/10.7759/cureus.7934 
29. Yin, I.X., Zhao, I.S., $\quad$ Mei, M.L., Li, Q., Yu, O.Y., Chu, C.H. Use of Silver Nanomaterials for Caries Prevention: A Concise Review International Journal of Nanomedicine 15 2020: pp. 3181-3191. https://doi.org/10.2147/IJN.S253833

30. Hershkovitz, F., Cohen, O., Zilberman, U. Microhardness of Three Glass-Ionomer Cements During Setting and up to 15 Days in vitro, and after 5 to 10 Years in vivo Quintessence International 51 (6) 2020: pp. 440-446. https://doi.org/10.3290/j.qi.a44372

31. Sidhu, S. K. Glass-Ionomer Cement Restorative Materials: a Sticky Subject? Australian Dental Journal 56 2011: pp. 23-30. https://doi.org/10.1111/j.1834-7819.2010.01293.x

32. Ruengrungsom, C., $\quad$ Burrow, M.F., $\quad$ Parashos, P., Palamara, J.E.A. Evaluation of F, Ca, and P Release and
Microhardness of Eleven Ion-leaching Restorative Materials and the Recharge Efficacy Using a new $\mathrm{Ca} / \mathrm{P}$ Containing Fluoride Varnish Journal of Dentistry 102 2020: pp. 103474 https://doi.org/10.1016/j.jdent.2020.103474

33. Magni, E., Ferrari, M., Hickel, R., Ilie, N. Evaluation of the Mechanical Properties of Dental Adhesives and GlassIonomer Cements 2010: pp. 79-87. https://doi.org/10.1007/s00784-009-0259-3

34. Molina, G.F., Cabral, R.J., Mazzola, I., Lascano, L.B., Frencken, J.E. Mechanical Performance of Encapsulated Restorative Glass-Ionomer Cements for use with Atraumatic Restorative Treatment (ART) Journal of Applied Oral Science 21 (3) 2013: pp. 243-249. https://doi.org/10.1590/1679-775720130129 International License (http://creativecommons.org/licenses/by/4.0/), which permits unrestricted use, distribution, and reproduction in any medium, provided you give appropriate credit to the original author(s) and the source, provide a link to the Creative Commons license, and indicate if changes were made. 